\title{
Factor Supporting Companies Performing Transfer Pricing
}

\author{
Nurjannah ${ }^{1}$, Muh Haekal Yunus ${ }^{2}$, Renaldi $^{3}$, Munawir ${ }^{4}$, Rafiqah Asaff ${ }^{5}$ \\ 1,2,3,4,5 Universitas Andi Djemma, Palopo City, South Sulawesi, Indonesia \\ Email Address: \\ anna.asaf1973@unanda.ac.id
}

\begin{abstract}
This study examines the effect of taxes, tunneling incentives, and bonus mechanisms on transfer pricing. The population in this study is the financial statements of primary and chemical industry companies listed on the Indonesia Stock Exchange in the 2018-2020 period, totaling 64 companies obtained through the official website of the Indonesia Stock Exchange (www.IDX.co.id.) This study's sample was obtained using the purposive sampling method; the total sample is 39 data from 13 financial statements of the primary and chemical industry sector for three years. Secondary data was collected through the Indonesia Stock Exchange website and analyzed using Multiple Regression Analysis with the Ordinary Least Square model using the Eviews Version 12 software. The results found that the tax variable shows a positive and significant effect on the occurrence of transactions transfer pricing. Meanwhile, the variable tunneling incentive and the bonus mechanism have no significant effect on transfer pricing.
\end{abstract}

Keywords: Taxes, Tunneling Incentives, Bonus Mechanisms, Transfer Pricing.

Abstrak: Penelitian ini bertujuan untuk menguji pengaruh pajak, tunneling insentive dan mekanisme bonus terhadap transfer pricing. Populasi dalam penelitian ini adalah laporan keuangan perusahaan sektor industri dasar dan kimia yang terdaftar di Bursa Efek Indonesia pada periode 2018-2020 yang berjumlah 64 perusahaan yang didapatkan melalui website resmi Bursa Efek Indonesia (www.idx.co.id.) Sampel pada penelitian ini didapat dengan menggunakan metode purposive sampling maka total sampel adalah 39 data dari 13 laporan keuangan sektor industri dasar dan kimia selama tiga tahun. Data sekunder dikumpulkan melalui website Bursa Efek Indonesia dan dianalisis menggunakan Analisis Regresi Berganda dengan model Ordinary Least Square menggunakan bantuan software Eviews Versi 12. Hasil penelitian menemukan bahwa variabel pajak menunjukkan pengaruh positif dan signifikan terhadap terjadinya transaksi transfer pricing. Sedangkan variabel tunneling insentive dan mekanisme bonus tidak berngaruh signifikan terhadap transfer pricing.

Kata Kunci: Pajak, Tunneling Insentive, Mekanisme Bonus, Transfer Pricing.

\section{INTRODUCTION}

Globalization causes the economy to develop without knowing national boundaries (Ahmad et al., 2018). This will impact multinational companies to face the problem of differences in tax rates that apply in each country. One of the main problems facing foreign investment is transfer pricing (Arsyad et al., 2021). Transfer pricing raises several problems 
and is quite challenging to solve because it relates to customs duties, anti-dumping provisions, and unfair business competition (Wooton and Zanardi, 2002). Although some companies are willing to adjust prices reasonably in one policy, it immediately creates two contradictions from other companies (Monsenego, 2015).

Transfer pricing is classified into two: determining transfer prices between divisions within the same company and determining transfer prices for transactions between companies with unique relationships (Huda et al., 2017). The transfer pricing method for transactions between divisions within the same company is called intra-company transfer pricing. At the same time, the method of determining transfer prices between companies with a special relationship is called inter-company transfer pricing. Transfer pricing for goods and services is one of the significant differences between domestic and foreign operations management controls. Several other essential considerations are needed to arrive at a transfer pricing decision (Azizah and Poren, 2014). These considerations include taxes, tunneling incentives, and bonus mechanisms (Pratama, 2018).

Companies initially carried out this transfer pricing practice solely to assess the performance between members or divisions of the company (Sa'diah and Afriyenti, 2021), but along with the times, transfer pricing practices are often also used for tax management, namely an attempt to minimize the amount of tax to be paid (Tiwa et al., 2017). Furthermore, (Fitri et al., 2019) stated that from a government perspective, transfer pricing is believed to result in a reduction or loss of a country's potential tax revenue because multi-national companies tend to shift their tax obligations from countries with high tax rates ( high tax countries) to countries that apply low tax rates (low tax countries). From a business point of view, companies have a tendency to try to minimize costs (cost efficiency), including minimizing corporate income tax payments. For global-scale companies (multi-national corporations), transfer pricing is believed to be one of the effective strategies to win the competition for limited resources (Mulyani et al., 2020). The main goal of international tax planning is to minimize the worldwide tax burden on companies.

Transfer pricing cases of multinational companies have occurred, such as Google, Starbucks, and Amazon (www.bbc.com). Starbucks UK, for example, uses several tactics to manipulate profits by transferring profits overseas. The first tactic is to do offshore licensing. Starbucks UK claims that they do not own the intellectual property of the recipe license, logo, and design. The intellectual property rights are held by a Dutch company called Starbucks Coffee EMEA BV. Therefore, every year Starbucks UK pays a sizeable licensing fee when it does so to transfer profits to the Netherlands. The Dutch company's income from the UK is classified as royalty and is subject to a minimum tax under Dutch tax regulations. The second tactic that Starbucks uses has to do with purchasing coffee. Starbucks UK purchases coffee beans from the Starbucks unit based in Switzerland. Therefore, Starbucks UK incurs a purchase fee for the coffee ore. Starbucks UK has done their way of managing their corporate tax. By Starbucks Switzerland, the transfer of the coffee ore is categorized as a commodity sale under Swiss tax regulations is only subject to a $2 \%$ rate.

The transfer pricing practice has also been carried out by PT Adaro Indonesia, which sells coal to Coaltrade Services International Pte. Ltd. (affiliated company located in Singapore). The coal transfer price was below the market price; then, by Coaltrade, this coal was resold at the market price. Of course, the transfer pricing practice carried out by PT Adaro is very detrimental to Indonesia because the revenues and profits obtained by PT 
Adaro in Indonesia are lower. This transfer pricing practice was revealed because there were suspicions about Coaltrade's 2002-2005 financial statement documents. In the financial statements, it can be seen that Coaltrade's profit is higher than Adaro's. This is possible given that Adaro owns a large mine but earns less profit.

The existence of this transfer pricing practice is often associated with the existence of taxes. In general, fiscal authorities must pay attention to two basic things so that tax corrections on alleged transfer pricing get a strong justification, namely affiliation (associated enterprises) or unique relationships, and fairness or arm's length principle (Rosa et al., 2017). In almost every tax law, you can find rules governing the tax treatment of transactions between parties with a special relationship. The regulation is the legal basis for the tax authorities to make corrections on transactions between parties with a special relationship and is considered a rule that can solve transfer pricing problems.

Law Number 7 of 1983, as last amended by Law Number 36 of 2008 concerning Income Tax, also has regulations that deal with transfer pricing issues, namely Article 18. Transfer pricing rules usually cover several things: understanding of unique relationships, authority determining the ratio of debt and equity, and the authority to make corrections in the event of transactions that are not arm's length. Law Number 36 of 2008 regulated in Article 18 paragraph (4) explains that a special relationship between a Corporate Taxpayer can occur due to the ownership or control of share capital of an entity by another entity as much as $25 \%$ (twenty-five percent) or more, or between several entities whose $25 \%$ (twentyfive percent) or more shares are owned by an entity. A special relationship can result in unfair prices, fees, or other rewards realized in a business transaction.

Universally, transactions between taxpayers who have a special relationship are known as transfer pricing. This can result in the transfer of income, tax base, or costs from one taxpayer to another that can be engineered to reduce the total amount of tax payable for the taxpayer who has a special relationship (Wafiroh and Hapsari, 2015). Experts recognize that transfer pricing allows companies to avoid double taxation and is also open to abuse because this can be used to shift profits to countries with low tax rates by maximizing expenses and, ultimately, income (Nuradila and Wibowo, 2018).

One aspect that influences transfer pricing decisions is tunneling incentives or transferring assets and profits out of the company for the benefit of the company's controlling shareholder (Chen et al., 2017). One example of tunneling activities is not distributing dividends, selling assets or securities from companies they control to other companies they own at below-market prices and selecting family members who do not meet the qualifications to occupy important positions in the company. (Krisdianto et al., 2019), Tunneling can be done by selling products to companies with unique relationships at lower prices. (Lo et al., 2010) stated that the concentration of ownership by the government in China affects transfer pricing decisions, where companies are willing to sacrifice tax savings for tunneling profits to the parent company. Several studies on taxes and their relation to transfer pricing decisions have been carried out, such as (Jafri and Mustikasari, 2018; Rachmat, 2019; Wijaya and Amalia, 2020) finding that taxes have a positive and significant effect on transfer pricing. Meanwhile, the results of research (Saraswati and Sujana, 2017; Purwanto and Tumewu, 2018) found that taxes did not affect transfer pricing decisions.

Another aspect that can influence the decision to transfer pricing is the bonus mechanism. According to (Rachmat, 2019), a bonus is an award given by the GMS to members of the Board of Directors if the company makes a profit. This bonus system will 
have an influence on management in profit engineering. Managers will tend to take actions that regulate net income to maximize the bonuses they will receive, including transfer pricing. This is supported by several previous researchers who studied the bonus mechanism on transfer pricing decisions (Saifudin and Putri, 2018; Fitri et al., 2019), suggesting that the bonus mechanism has a positive and significant influence on transfer pricing decisions. (Saraswati and Sujana, 2017; Sari and Puryandani, 2019; Mineri and Paramitha, 2021) found that the bonus mechanism had no significant effect on transfer pricing. Research on tunneling incentives on transfer pricing decisions is also investigated by (Indriaswari and Nita, 2018; Putri, 2019; Winarso, 2019), showing that tunneling incentives have a positive and significant effect on transfer pricing decisions. However, the research results from (Saifudin and Putri, 2018; Mulyani et al., 2020) find that tunneling incentives on transfer pricing decisions have no significant effect on transfer pricing.

\section{THEORITICAL REVIEW}

In this study, we use agency theory which is the theoretical basis that underlies the company's business practices used so far. Agency theory is rooted in economic theory, decision theory, sociology, and organizational theory synergy. The main principle of this theory states that there is a working relationship between the party who gives the authority (principal), namely the investor, and the party who receives the authority (agency), namely the manager, in the form of a cooperation contract called a nexus of contract (Bendickson et al., 2016). Agency theory describes two conflicting economic actors: the principal and the agent. An agency relationship is a contract in which one or more people (principals) instruct another person (agent) to perform a service on behalf of the principal and authorize the agent to make the best decisions for the principal (Soudry, 2007). If the principal and the agent have the same goal, the agent will support and carry out everything ordered by the principal. Agency problems can occur if the agent does not carry out the principal's orders for his benefit. In this study, the government is the principal while the company is the agent. The government acts as the principal orders the company to pay taxes by the tax laws. What happens is that the company as an agent prioritizes its interests in optimizing the company's profits to minimize the burden, including the tax burden by avoiding tax. Because taxes are a burden for companies that can reduce company profits, companies will look for ways to reduce the tax burden (Herawati and Ekawati, 2016). Agency theory can solve problems that occur related to agency relationships. Agency relationship problems that arise because of differences in interests between the parties, one side of the agent wants an increase in bonuses, while the principal wants to reduce tax costs. This theory arises because of asymmetric information, namely the information gap obtained by investors with information issued by management. (Martínez- Ferrero et al., 2016) states that information asymmetry is when managers have different information about the company's prospects than investors.

This study also uses signaling theory which emphasizes the quality of information released, which influences the economic decisions of outsiders. Information is the most crucial element for investors to know the company's condition in the past, present, and prospects in the future. The information needed by investors to avoid their occurrence must be relevant, complete, accurate, and timely to serve as the basis for analyzing economic decisions. Signaling theory in communication science is used by managers as a medium for delivering information to the public. Information published by the company's management 
signals investors and potential investors to make investment decisions. If the announcement published is positive, it is expected that the market will react when the announcement of earnings information is announced (Syed and Bajwa, 2018). The market reaction can be seen from changes in the volume of share sales. One type of information that can be used as a signal by the company to outsiders, especially investors, is the annual report. In the annual report, there are two types of information, namely accounting information in the form of financial statements and non-accounting information, namely information that is not related to financial statements. The annual report should disclose relevant and valuable information to the parties using the information. If the company wants its shares to be purchased by investors and potential investors, it must disclose information openly and transparently.

The relationship between signal theory and transfer pricing is that companies will allocate their income from countries with high tax rates to countries with lower tax rates to minimize total costs and maximize company profits. This is one of the signals about issues from the company which will be good news that the company has high profits on the company's annual income statement so that it gives the impression that the company will last a long time in the future (Junaidi and Yuniarti, 2020). Various information is focused on the relationship between taxes and the practice of transfer pricing. The strong relationship between taxes and transfer pricing is that the tax burden imposed by the state on companies causes companies to make sales at lower prices to related entities and transfer these profits to countries with low tax rates so that the company's profits will be maximized. (Winarso, 2019). In addition, taxes can affect the practice so that tax avoidance occurs, which can be achieved by transferring goods to a country with a low tax rate or a tax haven country and then transferring the goods back to a country that has a high potential for transfer pricing practices (Sikka and Willmott, 2010).

Positive accounting theory explains why accounting policies become a problem for companies and parties interested in financial statements and estimate what accounting policies companies should choose in certain situations (Rosa et al., 2017). Haryadi et al. (2020) mention that Positive Accounting Theory can explain why accounting policies are a problem for companies and parties interested in financial statements and predict accounting policies that companies want to choose under certain conditions. Positive accounting theory proposes three earnings management hypotheses: the bonus program hypothesis, the debt covenant hypothesis, and the political cost hypothesis. (Hiemann and Reichelstein, 2012) mentions that multinational companies carry out transfer pricing to minimize their global tax liability. Then according to (Purwanto and Tumewu, 2018), the tax motivation in transfer pricing in multinational companies is carried out by transferring income to the country with the lowest or minimum tax burden where the country has a group of companies or company divisions operating.

Agency theory can solve problems that occur related to agency relationships. Agency relationship problems that arise because of differences in interests between the parties, one side of the agent wants an increase in bonuses, while the principal wants to reduce tax costs. The relationship between signal theory and transfer pricing is that companies will allocate their income from countries with high tax rates to countries with lower tax rates to minimize total costs and maximize company profits. This is one of the signals about issues from the company which will be good news that the company has high profits on the company's annual income statement so that it gives the impression that the company will last a long time in the future (Junaidi and Yuniarti, 2020). Various information is focused on the 
relationship between taxes and the practice of transfer pricing. The strong relationship between taxes and transfer pricing is that the tax burden imposed by the state on companies causes companies to make sales at lower prices to related entities and transfer these profits to countries with low tax rates so that the company's profits will be maximized. Lestari \& Putri, 2017). Research results from (Tiwa et al., 2017; Jafri and Mustikasari, 2018; Rachmat, 2019; Wijaya and Amalia, 2020) found that taxes have a positive and significant effect on transfer pricing. Developing countries, including Indonesia, have believed that multinational companies established in Indonesia use the loopholes in existing tax regulations abroad to transfer company revenues and profits abroad through transfer pricing practices in various ways, rebuttals, and justifications for manipulation of these transactions, thereby reducing Indonesia's tax revenues (Saraswati and Sujana, 2017). Different research results are shown by (Purwanto andTumewu, 2018; Mineri and Paramitha, 2021), finding that taxes do not affect transfer pricing.

H1: Tax has a positive and significant effect on Transfer Pricing Decision.

Tunneling is the behavior of management or majority shareholders who transfer company assets and profits for their interests, but fees are charged to minority shareholders (Susanti and Firmansyah, 2018). Ownership structure reflects the type of agency conflict that occurs. There are two kinds of ownership structures: the structure of scattered ownership and concentrated ownership (Rosa et al., 2017). The dispersed ownership structure is characteristic that company management is controlled by managers (Mehrani et al., 2011). Agency theory describes two conflicting economic actors: the principal and the agent. Managers prioritize their interests over the interests of shareholders. In this ownership structure, shareholders are generally unwilling to carry out monitoring because they have to bear all the monitoring costs and only enjoy profits according to their share ownership. If all shareholders behave the same way, there will be no control over management. Thus, the agency conflict in the dispersed ownership structure is an agency conflict between managers and shareholders (Jensen and Smith, 2000). Research on tunneling incentives on transfer pricing decisions has been investigated by (Wafiroh and Hapsari, 2015; Indriaswari and Nita, 2018; Putri, 2019; Winarso, 2019), showing that tunneling incentives have a positive and significant effect on transfer pricing decisions. Transactions between related parties are used to transfer other current assets out of the company through unfair pricing for the benefit of the controlling shareholder. Purchasing goods or services above fair value and selling goods or services below fair price is one way of doing tunneling (Saraswati and Sujana, 2017). Different research results (Saifudin and Putri, 2018; Rahayu et al., 2020; Mulyani et al., 2020) found that on transfer pricing decisions have no significant effect on transfer pricing.

H2: tunneling incentives has a positive and significant effect on Transfer Pricing Decision.

In carrying out their duties, directors tend to show good performance to company owners. Because if the company owner or shareholders have assessed the directors' performance with a reasonable assessment, then the company owner will give awards to the directors who have managed their company well (Saifudin and Putri, 2018). The award can be in the form of a bonus given to the company's directors. In giving bonuses to the directors, 
the owner of the company will see the directors' performance in managing the company. In assessing the directors performance, the owner of the company usually looks at the company's overall profit generated. This is supported by the opinion (Nguyen et al., 2017), which states that directors' compensation (bonus) is seen from the performance of various divisions or teams in one organization. The greater the overall company profit generated, the better the image of the directors in the eyes of the company owner. Therefore, the directors can do everything they can to maximize its profits, including transfer pricing practices. Referring to research (Lo et al., 2010), there is a tendency for management to use transfer pricing transactions to maximize the bonuses they receive if the bonus is based on profit. So it can be concluded that managers will tend to take actions that regulate net income by carrying out transfer pricing practices to maximize the bonuses they receive. Research on the bonus mechanism on transfer pricing decisions was also investigated by (Saifudin and Putri, 2018); (Rachmat, 2019) and (Fitri et al., 2019), suggesting that the bonus mechanism has a positive and significant effect on transfer pricing decisions. (Saraswati and Sujana, 2017; Rosa et al., 2017; Purwanto and Tumewu, 2018; Sari and Puryandani, 2019; Mineri and Paramitha, 2021) Found that the bonus mechanism had no significant effect on transfer pricing.

H3: bonus mechanism has a positive and significant effect on Transfer Pricing Decision.

\section{METHODS}

This type of research includes causal research using quantitative methods. The population in this study is the financial statements of all primary and chemical industrial sector companies listed on the Indonesia Stock Exchange in the 2018-2020 period, totaling 64 companies obtained through the official website of the Indonesia Stock Exchange, namely www.idx.co.id. The sample in this study was obtained using the purposive sampling method.

Table 1. Sampling Criteria

\begin{tabular}{clc}
\hline No & \multicolumn{1}{c}{ Criteria } & Total \\
\hline 1 & $\begin{array}{l}\text { Companies listed on the Indonesia Stock Exchange (IDX) in the 2018-2020 } \\
\text { period in the basic and chemical industrial sectors. }\end{array}$ & 64 \\
2 & $\begin{array}{l}\text { Companies that do not publish financial statement data consecutively in the } \\
\text { 2018-2020 period. }\end{array}$ & $(9)$ \\
3 & Companies whose controlling share ownership is below 20\%. & $(15)$ \\
4 & Companies that experience losses during the observation period. & $(17)$ \\
5 & Companies that do not present their financial statements in rupiah. & $(10)$ \\
& $\quad$ Number of companies & 13 \\
The number of samples used in the study are 13 financial statements X three years & 39
\end{tabular}

Based on table 1, it can be seen that the number of samples used is 39 financial statements from 13 companies in the basic and chemical industry sector in the 2018-2020 period that have met predetermined criteria. This panel data is a combination of time series data and cross section data, where the time series is a collection of observations within a certain time span. Meanwhile, the cross section is data collected within a certain period of time from the sample through the website www.idx.co.id and analyzed using the multiple 
linear regression analysis method with the Ordinary Least Square model using the software Eviews Version 12. The data in this study will be tested in several stages of testing such as the classical assumption test (normality test, autocorrelation test, multicollinearity and heteroscedasticity test). The three hypotheses proposed in this study will be analyzed through the coefficient of determination test, simultaneous test and partial test.

Transfer pricing is the determination of prices or rewards related to the delivery of goods, services or transfer of technology between companies that have a special relationship and a systematic manipulation of prices with the intention of artificially reducing profits, which is made as if the company is experiencing a loss so as to avoid taxes or duty in a country (Sunady, 2011). Transfer Pricing in this study was measured using the following formula (Refgia, 2017).

$$
\text { Transfer Pricing }=\frac{\text { Receivables from Related Party Transactions }}{\text { Total Accounts Receivable }} \times 100 \%
$$

Taxes are mandatory contributions for individuals and entities to the state who have met specific requirements as taxpayers, where these contributions are used for the benefit of the wider community (Ratnawati, 2012). Taxes in this study were measured using the following formula (Yuniashi, 2015).

$$
\mathrm{ETR}=\frac{\text { Tax expense }}{\text { Profit before } \text { tax }} \mathrm{X} 100 \%
$$

Tunneling incentive is the behavior of the majority shareholder who transfers the company's assets and profits for his own sake. However, the minority shareholder shares the costs charged by the majority shareholder (Hartati and Julita, 2015). Tunneling incentive in this study was measured using the following formula (Yuniashi, 2015).

$$
\mathrm{TNC}=\frac{\text { The Largest Number of Shareholdings }}{\text { Total Shares Outstanding }} \times 100 \%
$$

The bonus mechanism is the provision of rewards other than salary to company directors for the work done by looking at the director's work performance. Work performance can be assessed and measured based on an assessment that has been determined by the company objectively. The independent variable in this study is the bonus mechanism. The bonus mechanism variable is proxied by the net profit trend index (ITRENDLB). The measurement of this variable uses a ratio scale with the following formula (Winda Hartati et al., 2014).

$$
\text { ITRENDLB }=\frac{\text { Net Profit Year }(t)}{\text { Net Profit Year } t-1}
$$

\section{RESULTS}

The decision of whether the residuals are normally distributed or not is simple by comparing the (probability valueJarque-Beracalculated)with an alpha level of $0.05(5 \%)$. When Prob. JB count greater than 0.05, it can be concluded that the residuals are normally distributed and vice versa; if the value is smaller, then there is not enough evidence to state 
that the residuals are normally distributed (Iqbal, 2018). The results of data normality using the average probability plot graph found that the data in this study were average and could be used.

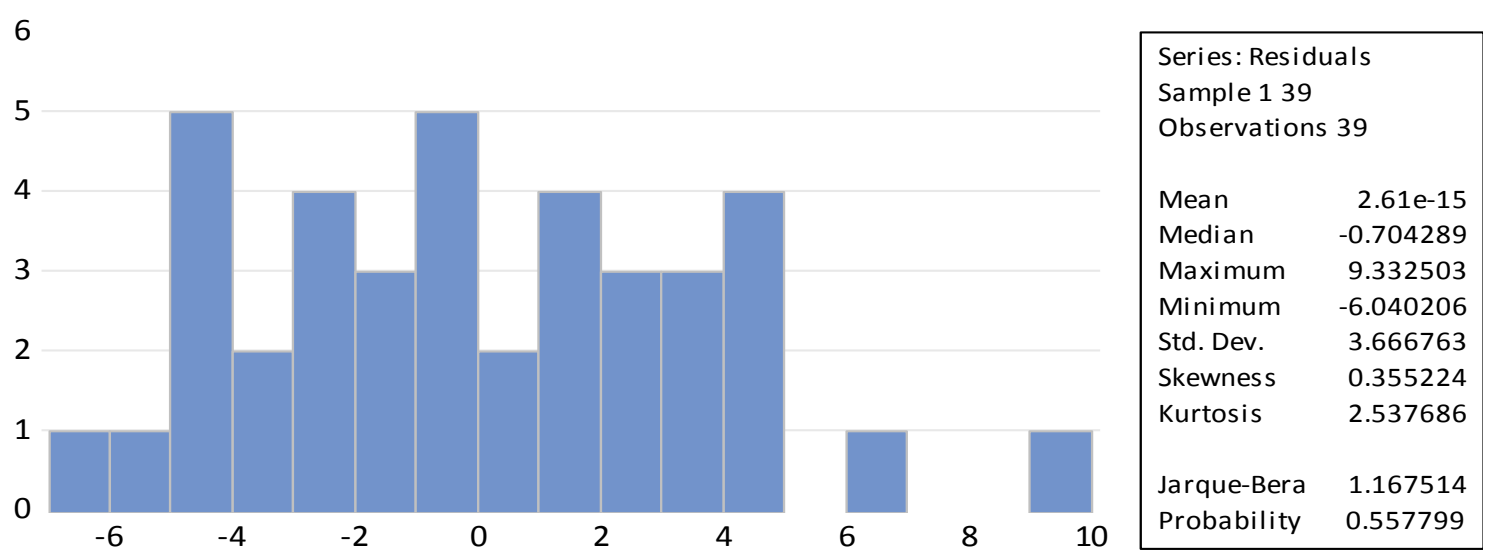

Figure 1. Normality Test Results Source : Output Eviews V.12 (2021)

Figure 1 shows the Jarque-Bera value of 1.167514 and a significance of 0.557799 or $55.70 \%>5 \%$ significance level; These results indicate that the data used in this study are typically distributed. The value of the calculated $\mathrm{F}$ probability must be greater than the alpha level of $0.05(5 \%)$. It can be said that there is no autocorrelation in the multiple linear regression model. On the other hand, if the value of Prob. F-count is smaller than 0.05; it can be concluded that there is autocorrelation. Furthermore, to ensure that the estimated data is free from autocorrelation, this study uses the Brusch-Godfrey method, as shown in table 2.

Table 2. Autocorrelation Test Results

\begin{tabular}{llc}
\hline No & Info & Breusch-Godfrey Test \\
\hline 1 & F. Statistik & 0,429 \\
& Prob. F & 0,733 \\
2 & Obs* R-Square & 1,383 \\
& Prob. Chi-Square & 0,709 \\
\hline
\end{tabular}

Source : Output Eviews V.12 (2021)

Based on table 2, the value of Prob. F of 0.733 is greater than the 5\% significance level so that there is no autocorrelation. Furthermore, a heteroscedasticity test was carried out to see whether disturbances appeared in the regression function. Heteroscedasticity in this study uses the heteroscedasticity test method using the ARCH method to decide whether or not heteroscedasticity occurs in the regression model. If the value of Prob. If the F-count is greater than the alpha level of $0.05(5 \%)$, then there is no heteroscedasticity, whereas if the Prob value. If the F-count is smaller than the alpha level of $0.05(5 \%)$, heteroscedasticity occurs. 
Table 3. Heteroskedasticity Test Arch Results

\begin{tabular}{llc}
\hline No & Info & Arch Test \\
\hline 1 & F. Statistik & 0,645 \\
& Prob. F & 0,426 \\
2 & Obs* R-Square & 0,669 \\
& Prob. Chi-Square & 0,413 \\
\hline
\end{tabular}

Source: Output Eviews V.12 (2021)

Based on table 3, the value of Prob. From F-count of 0.645 and Prob. The Chi-Square count is 0.426 , meaning that from all tests, it is greater than the $5 \%$ significance value, so there is no heteroscedasticity in the equation model. The multicollinearity test in this study used Variance Inflation Factors (VIF). If the Centered Variance Inflation Factors (VIF) value is less than or not greater than 10 or 5 , it can be said that there is no multicollinearity.

Table 4. Multikolinearitas Result

\begin{tabular}{llc}
\hline No & Auxiliary & Variance Inflation Factors (VIF). \\
\hline 1 & Tax & 0,421 \\
2 & Tunelling Incentive & 0,766 \\
3 & Bonus Mechanism & 0,198 \\
\hline Source: & Output Eviews V.12 (2021)
\end{tabular}

Based on table 4, the test results show that the coefficient value between variables is less than 0.9 , so the data in this study does not have a multicollinearity problem.

Tabel 5. Simultaneous Test

\begin{tabular}{llc}
\hline No & Info & Simultaneous Test \\
\hline 1 & F. Statistik & 2,701 \\
& Prob. F & 0,005 \\
\hline
\end{tabular}

Source: Output Eviews V.12 (2021)

Based on table 5 , the result of the calculated $\mathrm{f}$ test is 2.701 , and the probability fstatistic is $0.005<0.05$, so the tax, tunneling incentive, and bonus mechanism simultaneously have a significant effect on transfer pricing in elemental and chemical industry companies listed on the Indonesia Stock Exchange. (IDX) in the 2018-2020 period.

Table 6. Coefficient of Determination

\begin{tabular}{lc}
\hline Info & Coefficient of Determination \\
\hline R-Squared & 0,388 \\
Adj. R-Squared & 0,318 \\
\hline
\end{tabular}

Source: Output Eviews V.12 (2021)

Based on table 6, the R-Square value is 0.388 while the Adjusted R Square value is 0.318 . The result of $\mathrm{R}$ Square of $38.80 \%$ tax, tunneling incentive, and bonus mechanism simultaneously has a significant effect on transfer pricing. 
Table 7. Partial Test Results

\begin{tabular}{lccc}
\hline \multicolumn{1}{c}{ Variable } & B & t & Sig. \\
\hline Contant & 3,515 & 0,663 & 0,511 \\
Tax & 0.513 & 2,498 & 0.017 \\
Tunelling Incentive & $-0,005$ & $-0,187$ & 0.852 \\
Bonus Mechanism & $-0,004$ & $-0,966$ & 0,340 \\
\hline
\end{tabular}

Based on table 7, the formula for the multiple regression model test results is as follows:

transfer pricing $=3,515+0,513$ tax $-0,005$ tunneling incentive $-0,004$ bonus mechanism $+\mathrm{e} \ldots(5)$

The tax variable on transfer pricing shows that the count value is smaller than t-table $(2,498>1,689)$ with a significance level $(p$-value $)=0.017(<0.05)$. Because the p-value $<$ a $(5 \%)$ and the coefficient are positive $0.513, \mathrm{H} 1$ is accepted, meaning that the tax a positive and significant effect on transfer pricing. Tunneling incentive variable on transfer pricing shows that the count value is smaller than t-table $(-0.187<1.689)$ with a significance level $(\mathrm{p}$-value $)=0.852(>0.05)$. Because the $\mathrm{p}$-value $<\mathrm{a}(5 \%)$ and the coefficient are negative $-0.005, \mathrm{H} 2$ is rejected, which means that the tunneling incentive has no significant effect on transfer pricing. The bonus mechanism variable on transfer pricing shows that the count value is smaller than t-table $(-0.966<1.689)$ with a significance level (p-value) $=$ $0.340(>0.05)$. The p-value $<\mathrm{a}(5 \%)$ and the coefficient is negative -0.004 ; thus, H3 is rejected, which means that the bonus mechanism has no significant effect on transfer pricing.

\section{DISCUSSION}

The results of testing the first hypothesis (H1) indicate that taxes positively and significantly affect transfer pricing. The results of this study indicate that the greater the value of the company's effective tax rate, the greater the tax burden the company will encourage companies to carry out transfer pricing. This is done by transferring the company's tax obligations to related companies located in other countries with lower tax rates than Indonesia.

It can be justified that the application of transfer pricing is still a means of tax avoidance by multinational companies and places an effective tax rate as a benchmark. In other words, the greater the amount of tax burden that must be paid by the company to the state, the more profit-oriented multinational companies are triggered to carry out various tips ini order to minimize the amount of tax burden that must be paid, one of which is by applying transfer pricing.

The results of this study support agency theory to solve problems related to agency relationships. Agency relationship problems arise because of differences in interests between the parties; one side of the agent wants bonuses. In contrast, the principal wants to reduce tax costs. The relationship between signal theory and transfer pricing is that companies will allocate their income from countries with high tax rates to countries with lower tax rates to minimize total costs and maximize company profits. This is one of the signals about issues from the company which will be good news that the company has high 
profits on the company's annual income statement so that it gives the impression that the company will last a long time in the future (Junaidi and Yuniarti, 2020). Various information is focused on the relationship between taxes and the practice of transfer pricing. The strong relationship between taxes and transfer pricing is that the tax burden imposed by the state on companies causes companies to make sales at lower prices to related entities and transfer these profits to countries with low tax rates so that the company's profits will be maximized. (Lestari and Putri, 2017). The results of this study support the results that have been found by (Tiwa et al., 2017; Jafri and Mustikasari, 2018; Rachmat, 2019; Wijaya and Amalia, 2020), finding that taxes have a positive and significant effect on transfer pricing. Developing countries, including Indonesia, have believed that multinational companies established in Indonesia use the loopholes in existing tax regulations abroad to transfer company revenues and profits abroad through transfer pricing practices in various ways, rebuttals, and justifications for manipulation of these transactions, thereby reducing Indonesia's tax revenues (Saraswati and Sujana, 2017). However, the results of this study are different from the results found by (Purwanto and Tumewu, 2018; Mineri and Paramitha, 2021), who found that taxes did not affect transfer pricing. Thus transfer pricing does not only involve between taxpayers and the tax authorities of a country but also involves two or more tax authorities in different countries.

Testing the second hypothesis (H2) shows that tunneling incentive is not significant for transfer pricing. This means that tunneling has no significant effect on transfer pricing decisions. This is because the company implements an effective supervisory mechanism and has high foreign controlling share ownership, which tends to act to avoid risk by not utilizing transfer pricing in the context of expropriation of minority shareholders because of the risk of causing conflicts that have an impact on the company's value decline and investors' lousy judgment. The results of this study do not support positive accounting theory, which explains that positive accounting theory proposes three earnings management hypotheses, namely (Bonus Program Hypothesis, Debt Agreement Hypothesis, and Political Cost Hypothesis). Agency theory describes two conflicting economic actors: the principal and the agent. Managers prioritize their interests over the interests of shareholders. In this ownership structure, shareholders are generally unwilling to carry out monitoring because they have to bear all the monitoring costs and only enjoy profits according to their share ownership. If all shareholders behave the same way, there will be no control over management. Thus, the agency conflict in the dispersed ownership structure is an agency conflict between managers and shareholders (Jensen and Smith, 2000). The results of this study support the research results (Saifudin and Putri, 2018; Rahayu et al., 2020; Mulyani et al., 2020), finding that tunneling incentives on transfer pricing decisions have no significant effect on transfer pricing. Tunelling incentive done by transferring profits company, so that the profit earned by the company is smaller because the profit has transferred to an affiliated company. As for the transactions carried out can be in the form out: sale or ourchase with affiliated companies by appliying transfer pricing. However, in contrast to the research results (Wafiroh and Hapsari, 2015; Indriaswari and Nita, 2018; Putri, 2019; Winarso, 2019) it shows that tunneling incentives have a positive and significant effect on transfer pricing decisions. The larger the shares owned by controlling shareholder, the greater the opportunity to carry out transfer pricing.

The results of testing the third hypothesis (H3) show that the bonus mechanism has no significant effect on transfer pricing. This means that the amount of profit does not make 
the directors decide to do transfer pricing because the directors or company management have set strategies to achieve the bonus targets they want to get from company owners by innovating strategies so that the possibility of transfer pricing will be possible be slighter. This situation is because the company is stable in earning profits, so it gives bonuses to the directors and the lack of intention to transfer pricing. The bonus earned is also determined by the resulting performance, the percentage of profit. If the profitability increases, the bonus earned will also increase. The two things will go hand in hand. Profitability is proven not to affect transfer pricing. This is closely related to the bonus mechanism, which does not affect transfer pricing (Amanah and Suyono, 2020). The results of this study support positive accounting theory, which explains that managers of companies with bonus plans tend to choose accounting procedures with changes in reported earnings from future periods to current periods. Managers want high rewards in each period. If their rewards depend on reported bonuses on net income, they are likely to increase their bonuses for the period by reporting the highest possible net income. Then, agency theory is not suitable for the results of this study because agency theory has explained the relationship between company management (agents) and shareholders (principals). In an agency relationship, there is a contract of one or more people (principals) that instructs another person (agent) to perform a service on behalf of the principal and authorizes the agent to make the best decision for the principal. The results of this study support the results of research (Saraswati and Sujana, 2017; Rosa et al., 2017; Purwanto and Tumewu, 2018; Sari and Puryandani, 2019; Mineri and Paramitha, 2021), which found that the bonus mechanism had no significant effect on transfer pricing. The company already has a good control system, where all activities carried out must comply with applicable company regulation and are supervised by commitess so that no fraud is commited to maximize company profits in order to obtain large bonuses. However, the results of this study are different from those (Saifudin and Putri, 2018; Rachmat, 2019; Fitri et al., 2019), suggesting that the bonus mechanism has a positive and significant effect on transfer pricing decisions.

\section{CONCLUSION}

Transfer pricing is a special selling price imposed on an item when making a sale or purchase transaction with a company with a special relationship or commonly referred to as an affiliated company. Where this transaction is carried out is to achieve a specific goal. The tax variable shows a positive and significant effect on the occurrence of transfer pricing transactions. Meanwhile, the tunneling incentive variable and the bonus mechanism have no significant effect on transfer pricing. The researcher proposes several suggestions to improve writing for further research. The sample used in this study only focuses on primary and chemical industrial sector companies listed on the Indonesia Stock Exchange (IDX), so it cannot be generalized to other types of industries. For further research, it is recommended to expand the research sample to manufacturing companies and companies operating in the mining, plantation, finance, and other sectors. In addition, the researcher also suggests adding other research variables that can affect the transfer pricing transaction. 


\section{REFERENCES}

Ahmad, H., Mappatompo, A., and Muslim, M. (2018). Capital Ownership Structure And Decision On Fi-financial Market Reaction And Corporate Value. International Journal of Innovative Science and Re-search Technology, 3(9), 395-406.

Amanah, K., dan Suyono, N. A. (2020). Pengaruh Profitabilitas, Mekanisme Bonus, Tunneling Incentive, Dan Debt Covenant Terhadap Transfer Pricing Dengan Tax Minimization Sebagai Variabel Moderasi. Journal of Economic, Business and Engineering (JEBE), 2(1), 1-13.

Arsyad, M., Haeruddin, S. H., Muslim, M., and Pelu, M. F. A. (2021). The effect of activity ratios, liquidity, and profitability on the dividend payout ratio. Indonesia Accounting Journal, 3(1), 36-44. https://doi.org/10.32400/iaj.30119.

Azizah, A. P. N., dan Poren, A. (2014). Pengaruh Pajak, Tunneling Incentive, dan Exchange Rate pada Keputusan Transfer Pricing Perusahaan. Jurnal Akuntansi Audit Indonesia, 18(2), 156-165.

Bendickson, J., Muldoon, J., Liguori, E., and Davis, P. E. (2016). Agency theory: the times, they are a-changin'. Management Decision. https://doi.org/10.1108/MD-02-20150058 .

Chen, W., Li, S., and Chen, C. X. (2017). How much control causes tunneling? Evidence from China. China journal of accounting research, 10(3), 231-245.

Fitri, D., Hidayat, N., and Arsono, T. (2019). The Effect of Tax Management, Bonus Mechanism and Foreign Ownership on Transfer Pricing Decision. Riset, 1(1), 36-48.

Haryadi, E., Sumiati, T., and Umdiana, N. (2020). Financial Distress, Leverage, Persistensi Laba Dan Ukuran Perusahaan Terhadap Konservatisme Akuntansi. Competitive Jurnal Akuntansi Dan Keuangan, 4(2), 66-77.

Herawati, H., dan Ekawati, D. (2016). Pengaruh perencanaan pajak terhadap nilai perusahaan. Jurnal Riset Akuntansi Dan Keuangan, 4(1), 873-884.

Hiemann, M., and Reichelstein, S. (2012). Transfer pricing in multinational corporations: An integrated management-and tax perspective. In Fundamentals of international transfer pricing in law and economics (pp. 3-18). Springer.

Huda, M. K., Nugraheni, N., and Kamarudin, K. (2017). The problem of transfer pricing in indonesia taxation system. International Journal of Economics and Financial Issues, 7(4).

Indriaswari, Y. N., and Nita, R. A. (2018). The influence of tax, tunneling incentive, and bonus mechanisms on transfer pricing decision in manufacturing companies. The Indonesian Accounting Review, 7(1), 69-78.

Jafri, H. E., dan Mustikasari, E. (2018). Pengaruh Perencaan Pajak, Tunnneling Incentive dan Aset Tidak Berwujud Terhadap Perilaku Transfer Pricing pada Perusahaan Manufaktur yang Memiliki Hubungan Istimewa yang Terdaftar di Bursa Efek Indonesia Periode 2014-2016. Berkala Akuntansi Dan Keuangan Indonesia, 3(2), 63 77.

Jensen, M. C., and Smith, C. W. (2000). Stockholder, manager, and creditor interests: Applications of agency theory. Theory of the Firm, 1(1).

Junaidi, A., dan Yuniarti, N. (2020). Pengaruh Pajak, Tunneling Incentive, Debt Covenant Dan Profitabilitas Terhadap Keputusan Melakukan Transfer Pricing. Jurnal Ilmiah Akuntansi, Manajemen Dan Ekonomi Islam (JAM-EKIS), 3(1), 31-44. 
Krisdianto, A., Fadah, I., Jember, K. S., and Puspitasari, N. (2019). Determinants of Transfer Pricing Decisions In Indonesian Multinational Companies. International Journal of Inovative Science and Research Technology 4(12), 899, 908.

Lestari, G. A. W., dan Putri, I. A. (2017). Pengaruh corporate governance, koneksi politik, dan leverage terhadap penghindaran pajak. E-Jurnal Akuntansi Universitas Udayana, 18(3), 2028-2054.

Lo, A. W. Y., Wong, R. M. K., and Firth, M. (2010). Tax, financial reporting, and tunneling incentives for income shifting: An empirical analysis of the transfer pricing behavior of Chinese-listed companies. Journal of the American Taxation Association, 32(2), 126.

Martínez-Ferrero, J., Ruiz-Cano, D., and García-Sánchez, I. (2016). The causal link between sustainable disclosure and information asymmetry: The moderating role of the stakeholder protection context. Corporate Social Responsibility and Environmental Management, 23(5), 319-332.

Mehrani, S., Moradi, M., and Esk, H. (2011). Ownership structure and dividend policy: Evidence from Iran. African Journal of Business Management, 5(17), 7516-7525.

Mineri, M. F., dan Paramitha, M. (2021). Pengaruh Pajak, Tunneling Incentive, Mekanisme Bonus Dan Profitabilitas Terhadap Transfer Pricing. Jurnal Analisa Akuntansi Dan Perpajakan, 5(1).

Monsenego, J. (2015). Introduction to transfer pricing. Kluwer Law International.

Mulyani, H. S., Prihartini, E., dan Sudirno, D. (2020). Analisis Keputusan Transfer Pricing Berdasarkan Pajak, Tunneling dan Exchange Rate. Jurnal Akuntansi Dan Pajak, 20(2), 171-181.

Nuradila, R. F., and Wibowo, R. A. (2018). Tax Minimization sebagai Pemoderasi Hubungan antara Tunneling Incentive, Bonus Mechanism dan Debt Convenant dengan Keputusan Transfer Pricing. JIFA (Journal of Islamic Finance and Accounting), 1(1).

Nguyen, T. T., Mia, L., Winata, L., and Chong, V. K. (2017). Effect of transformationalleadership style and management control system on managerial performance. Journal of Business Research, 70, 202-213.

Pratama, A. (2018). Do related party transactions and tax avoidance affect firm value? Review of Integrative Business and Economics Research, 7, 106-116.

Purwanto, G. M., dan Tumewu, J. (2018). Pengaruh Pajak, Tunneling Incentive dan Mekanisme Bonus Pada Keputusan Transfer Pricing Perusahaan Manufaktur yang Terdaftar Di Bursa Efek Indonesia. Equilibrium: Jurnal Ekonomi-ManajemenAkuntansi, 14(1), 47-56.

Putri, V. R. (2019). Analisis Faktor Yang Mempengaruhi Transfer Pricing Pada Perusahaan Manufaktur Di Indonesia. Jurnal Manajemen Dayasaing, 21(1), 1-11.

Rachmat, R. A. H. (2019). Pajak, Mekanisme Bonus dan Transfer Pricing. JPAK: Jurnal Pendidikan Akuntansi Dan Keuangan, 7(1), 21-30.

Rahayu, T. T., Wahyuningsih, E. M., dan Wijayanti, A. (2020). Pengaruh Beban Pajak, Exchange Rate, Tunneling Incentive, Profitabilitas dan Leverage Terhadap Keputusan Transfer Pricing. Jurnal Penelitian Ekonomi Dan Akuntansi (JPENSI), 5(1), 78-90.

Rosa, R., Andini, R., dan Raharjo, K. (2017). Pengaruh Pajak, Tunneling Insentive, Mekanisme Bonus, Debt Covenant Dan Good Corperate Gorvernance (GCG) 
Terhadap Transaksi Transfer Pricing (Studi Pada Perusahaan Manufaktur Yang Terdaftar Di Bursa Efek Indonesia Tahun 2013-2015). Journal Of Accounting, 3(3).

Sa'diah, F., dan Afriyenti, M. (2021). Pengaruh Tax Avoidance, Ukuran Perusahaan, dan Dewan Komisaris Independen terhadap Kebijakan Transfer Pricing. JURNAL EKSPLORASI AKUNTANSI (JEA), 3(3), 501-516.

Saifudin, S., dan Putri, S. (2018). Determinasi Pajak, Mekanisme Bonus, dan Tunneling Incentive terhadap Keputusan Transfer Pricing pada Emiten BEI. Agregat: Jurnal Ekonomi Dan Bisnis, 2(1), 32-43.

Saraswati, G., dan Sujana, I. K. (2017). Pengaruh pajak, mekanisme bonus, dan tunneling incentive pada indikasi melakukan transfer pricing. E-Jurnal Akuntansi Universitas Udayana, 19(2), 1000-1029.

Sari, A. N., dan Puryandani, S. (2019). Pengaruh Pajak, Tunneling Incentive, Good Corporate Governance Dan Mekanisme Bonus Terhadap Transfer Pricing (Studi Kasus pada Perusahaan Pertambangan yang Tercatat di BEI Periode 2014-2017). Sustainable Competitive Advantage (SCA), 9(1).

Sikka, P., and Willmott, H. (2010). The dark side of transfer pricing: Its role in tax avoidance and wealth retentiveness. Critical Perspectives on Accounting, 21(4), 342356.

Soudry, O. (2007). A principal-agent analysis of accountability in public procurement. Advancing Public Procurement: Practices, Innovation and Knowledge-Sharing, 432451.

Susanti, A., and Firmansyah, A. (2018). Determinants of transfer pricing decisions in Indonesia manufacturing companies. Jurnal Akuntansi Dan Auditing Indonesia, 22(2), 81-93.

Syed, A. M., and Bajwa, I. A. (2018). Earnings announcements, stock price reaction and market efficiency-the case of Saudi Arabia. International Journal of Islamic and Middle Eastern Finance and Management.

Tiwa, E. M., Saerang, D. P. E., dan Tirayoh, V. (2017). Pengaruh pajak dan kepemilikan asing terhadap penerapan transfer pricing pada perusahaan manufaktur yang terdaftar di BEI tahun 2013-2015. Jurnal EMBA: Jurnal Riset Ekonomi, Manajemen, Bisnis Dan Akuntansi, 5(2).

Wafiroh, N. L., dan Hapsari, N. N. (2015). Pajak, tunneling incentive dan mekanisme bonus pada keputusan transfer pricing. EL MUHASABA: Jurnal Akuntansi (e-Journal), 6(2), $157-168$.

Wijaya, I., and Amalia, A. (2020). Pengaruh Pajak, Tunneling Incentive, Dan Good Corporate Governance Terhadap Transfer Pricing. Profita: Komunikasi Ilmiah Dan Perpajakan, 13(1), 30-42.

Winarso, W. (2019). Pengaruh Pajak dan Tunneling Incentive Terhadap Keputusan Transfer Pricing Pada Perusahaan Pertambangan yang terdaftar di Bursa Efek Indonesia (BEI) Periode 2012-2017. Jurnal Ilmiah Akuntansi Dan Manajemen (JIAM), 15(1), 49-59.

Wooton, I., and Zanardi, M. (2002). Trade and competition policy: anti-dumping versus anti-trust. Citeseer. 